\title{
Chapter 12 \\ Globalization and Institutional Change in Italian Industrial Districts
}

\author{
Harald Bathelt and Nicolas Conserva
}

\section{Industrial Districts and Globalization Processes}

During the 1980s and 1990s, Italian industrial districts and their internal economic structure became a major field of academic inquiry in the social sciences, receiving a lot of attention as an alternative regional industry configuration that successfully resisted the trend toward mass production and large-firm dominance during the Fordist era. Especially the so-called Third Italy was celebrated for its ability to achieve growth on the basis of an agglomeration of small and medium-sized firms that were closely linked through regional production networks (Becattini, 1990; Becattini, Bellandi, \& de Propris, 2009; Belussi \& Pilotti, 2002; Brusco, 1982), characterized by localized learning processes and specialized institutional settings (Amin \& Thrift, 1995; for an overview of developments and debates see, Bathelt, 1998; Bathelt \& Glückler, 2012).

With globalization processes intensifying since the 1980s and pressure on firms and regions to become better integrated into the global economy, new challenges to growth have arisen in these industrial districts. The fundamental question raised by these developments is whether localized learning systems can survive in an era of increased global competition (Belussi \& Sedita, 2012; Camuffo \& Grandinetti, 2011; dei Ottati, 2009a, 2009b; Lan, 2015; Rabellotti, 2004; Whitford, 2001; Whitford \& Potter, 2007). In other words, how can the institutional settings of industrial districts and the mechanisms in place to support localized production and learning be modernized to enable economic growth in a globalizing world?

\footnotetext{
H. Bathelt $(\bowtie)$

Department of Political Science and Department of Geography and Planning,

University of Toronto, ON, Canada

e-mail: harald.bathelt@utoronto.ca

N. Conserva

Department of Political Science, University of Toronto, ON, Canada

e-mail: nicolas.conserva@mail.utoronto.ca
} 
To answer this question in this chapter, we employ a case study of the Canavese district in northern Italy, north of Turin. The region has an interesting economic structure in that it is characterized by two interlinked organizational fields (DiMaggio \& Powell, 1983), with a concentration of key suppliers, users, regulatory agencies, and other organizations in both the automotive-metallurgical and electronicsmechatronics industries. Canavese is home to the automotive producer Fiat and the electronics and minicomputer firm Olivetti that dominated the development of the two organizational fields. While somewhat different from other industrial districts that do not specialize in capital-intensive and technology-based industries, Canavese also established a localized production and learning system with a division of labor that was centered on the two lead firms (e.g., Albino, Garavelli, \& Schiuma, 1998; Giblin, 2011). With increasing global competitive pressure on Fiat and Olivetti, the entire region had to go through extensive restructuring processes beginning in the 1980s. Interestingly, both organizational fields underwent a similar institutional change, evolving from a context characterized by localized learning and a distinct regional manufacturing culture to a more global, open-learning based and interactive system, while maintaining regional linkages and reference points.

In this chapter we use the example of Canavese to show that it is advantageous from the perspective of regional economic development to employ a hybrid mix of elements combining institutional change with continuity to cope with the challenges of globalization. It is argued that successful regional restructuring of a localized production system cannot be based on radical technological and institutional shifts alone. While such restructuring requires that some fundamental institutional adjustments be initiated to encourage the formation of global linkages and new technological trajectories, the process also needs elements of continuity to support established industries and prior competitive advantages. In the context of this volume on knowledge and institutions, we demonstrate in this chapter how an institutional perspective is crucial in understanding spatially differentiated processes of economic and social change.

In the next section, we develop our conceptual argument and present a model that relates regional restructuring outcomes to different types of adjustments in the localized institutional context and the industry structure. This is followed by brief comments about the methodology applied and a description of the socioeconomic context of the Canavese region with Fiat and Olivetti. The analytical part of our study presents a systematic discussion of how the regional production system developed from a setting of localized learning into an open economic system, providing support for the conceptual model of industrial, institutional, and regional change. We conclude by considering policy implications.

\section{Regional Growth and Institutional Change}

In conceptualizing the process of how localized learning systems can adjust to globalization pressures and successfully restructure, we develop a perspective that pays particular attention to the role of the regional institutional context and its 
adjustments. This perspective links to other work in economic geography that has dealt with the dangers of regional lock-in and the challenges of maintaining regional resilience. There is a now broad literature on regional lock-in processes emphasizing the threats to innovation and economic growth that result if institutional settings become too rigid or are over-embedded in hierarchical power structures with few dominant actors (e.g., Hassink \& Shin, 2005; Martin \& Sunley, 2006). This literature focuses on ways to explain and avoid institutional rigidity. Other, more recent work has focused on the economic resilience of regions that experience external shocks. Related studies have investigated how regions are able to withstand or overcome such ruptures and return to their former growth paths (e.g., Hassink, 2010; Martin \& Sunley, 2015; Pike, Marlow, McCarthy, O’Brien, \& Tomaney, 2015). Although the studies on lock-in and economic resilience emphasize the importance of institutions in economic development, their analytical focus is on preventing interruptions to economic growth patterns, rather than on investigating the interdependencies between corporate adjustments and regional institutional change in generating a new regional development path. Especially in the context of fundamental ruptures, when localized learning systems are threatened by globalization processes, the institutional perspective applied in this chapter may be useful in exploring the potential for successful regional restructuring and discussing alternative scenarios of development (Bathelt \& Glückler, 2012; Glückler \& Bathelt, 2017).

\section{Institutions and Institutional Context}

An institutional perspective is crucial when analyzing regional economic development as a collective process because institutions enable economic actors to develop expectations of the behavior of other actors and reduce uncertainties in economic life (e.g., Hodgson, 1988; North, 1990). Firms will find it less risky to engage in collaborative practices, in particular when certain types of behavior can be enforced and deviations sanctioned. Like the "tricks of the trade" of how to behave in a certain environment, specific institutional settings are a prerequisite for the development of any sort of social division of labor. Therefore, when analyzing coherent economic structures, such as localized learning systems, special attention must be paid to the role of regional institutions that enable coordinated interaction and generate the conditions for the reproduction of such patterns (e.g., Rodríguez-Pose \& Storper, 2006). If such institutional settings are replaced by new types of institutions, learning processes that rely on a regional division of labor may change substantially and localized interaction patterns may disappear.

While most researchers in economic geography would agree with the above logic (e.g., Boschma \& Frenken, 2009), the understanding of institutions is often vague and the term institution used unspecifically to refer to all sorts of government influences on economic development. This causes misunderstandings as to how institutions operate (Bathelt \& Glückler, 2012, 2014). If, for instance, an established government initiative in a region introduces a new policy to stimulate economic 
growth, the question arises as to whether this is a case of institutional persistence (because it is carried out by an established organization) or institutional change (because of the introduction of a new policy). Our answer would clearly depend on the understanding of institutions applied. In the following, we argue for a careful and explicit definition of institutions.

We suggest looking at institutions in terms of how they shape economic interaction. In some studies, governments, banks, or pension funds are viewed as institutions (e.g., Clark \& Monk, 2013). However, in our perspective these are organizations, not institutions. A ministry for economic development, for instance, does not have an immediate impact on economic interaction. Nevertheless, it may decide upon and create new rules, regulations, and policies that are relevant for the firms in a region because these are intended to guide their behavior. In economics, institutions are therefore widely understood as rules and regulations (Gertler, 2010; North, 1991). In our view, however, such rules and regulations are not yet institutions. They establish a framework for actions but do not determine a specific form of action and interaction. For instance, a new regional start-up policy providing financial incentives may lead to innovative firm start-ups from local universities or it may trigger vertical disintegration in existing industries. In the first case, this may generate a regional context of individualistic technology start-ups; in the second, a trust-based division of labor in established industries may develop. This example suggests that rules and regulations can be interpreted differently by firms and may have a completely different outcome in terms of the unfolding regional practices and patterns of interaction. It is these latter patterns of correlated behavior (Setterfield, 1993) or planned and unplanned stabilizations of economic interaction (Bathelt \& Glückler, 2014) that we refer to as institutions in a narrow sense.

For an institutional analysis of regional economic change, it is clearly not enough to focus on only one of these institutional building blocks. As suggested by DiMaggio and Powell (1983, p. 147), "highly structured organizational fields provide a context in which individual efforts to deal rationally with uncertainty and constraint often lead, in the aggregate, to homogeneity in structure, culture, and output" [emphasis added]. When investigating the dynamics of organizational fields within a framework of regional change, it is therefore necessary to consider all levels of what we refer to as the institutional context, as well as their interplay (Glückler $\&$ Bathelt, 2017): the role of and linkages between institutional actors (individuals and organizations that generate rules), the rules and regulations that are created by them (and act as a framework for interaction), and the patterns of economic interaction that develop in practice (i.e., the institutions in a narrow sense). While these interconnections between organizations, rules, and practices have hardly been systematically studied in broader conceptual and empirical investigations, some extreme scenarios seem intuitively clear when considering the consequences of globalization processes. It is likely, for instance, that existing firms operating according to long-term rule systems with established practices may have a hard time adjusting to abrupt changes caused by globalization. Conversely, a large number of young firms that engage in emerging technology fields driven by new rules and regulations may develop flexible interaction patterns that make it quite easy to adjust to new 
Table 12.1 Regional restructuring scenarios as a response to globalization pressures

\begin{tabular}{|c|c|c|c|c|}
\hline \multirow{2}{*}{$\begin{array}{l}\text { Regional } \\
\text { restructuring } \\
\text { scenarios }\end{array}$} & & \multicolumn{3}{|c|}{ Adjustments in the regional institutional context } \\
\hline & & Persistence & Hybrid change & $\begin{array}{l}\text { Fundamental } \\
\text { change }\end{array}$ \\
\hline \multirow{6}{*}{$\begin{array}{l}\text { Adjustments } \\
\text { in the regional } \\
\text { industry and } \\
\text { corporate } \\
\text { structure }\end{array}$} & Persistence & $\begin{array}{l}\text { - Loss of corporate } \\
\text { competitiveness }\end{array}$ & $\begin{array}{l}\text { - Institutional stimulus } \\
\text { unsuccessful }\end{array}$ & $\begin{array}{l}\text { - New institutions } \\
\text { do not match }\end{array}$ \\
\hline & & $\begin{array}{l}\text { - No effects of } \\
\text { regional learning }\end{array}$ & $\begin{array}{l}\text { - Stagnation of } \\
\text { regional learning }\end{array}$ & $\begin{array}{l}\text { - Loss of regional } \\
\text { learning base }\end{array}$ \\
\hline & & - Regional decline & base & - Regional crisis \\
\hline & Change & $\begin{array}{l}\text { - Limited new } \\
\text { learning patterns } \\
\text { develop }\end{array}$ & $\begin{array}{l}\text { - New and old industries } \\
\text { integrated in new and } \\
\text { established learning cycles }\end{array}$ & $\begin{array}{l}\text { - New industries } \\
\text { supported by new } \\
\text { institutions }\end{array}$ \\
\hline & & $\begin{array}{l}\text { - Hollowing out of } \\
\text { regional learning } \\
\text { platform }\end{array}$ & $\begin{array}{l}\text { - Growth in global } \\
\text { economy consistent with } \\
\text { localized learning }\end{array}$ & $\begin{array}{l}\text { - Established } \\
\text { industries left } \\
\text { behind }\end{array}$ \\
\hline & & $\begin{array}{l}\text { - Slow regional } \\
\text { change }\end{array}$ & & $\begin{array}{l}\text { - Bifurcated } \\
\text { regional structure }\end{array}$ \\
\hline
\end{tabular}

Source: Design by authors

global structures. Nevertheless, the institutional context cannot exclusively concentrate on such young firms and emerging technologies. The challenges of globalization in the localized learning context of an industrial district also have to be met by existing firms operating in established technologies according to long-established practices of production and marketing. It is therefore fundamental to develop bridging and connecting capabilities between established and new practices to trigger broader, more inclusive regional change.

\section{Industrial, Institutional, and Regional Change}

To discuss the institutional context of regional economic change in more detail, we introduce a simple model that can be applied to the situation of a localized learning system, which is challenged by globalization processes. The model, summarized in Table 12.1, presents different scenarios of regional economic change in relation to two factors: (i) adjustments in the regional industry and corporate structure and (ii) adjustments in the regional institutional context. We assume that these two types of changes can originally occur independently but that at later stages industrial change can influence or trigger institutional adjustments and vice versa (Glückler \& Lenz, 2016). Inspired by the studies of Douglas and Hargadon (2017), Scott (1998), and Streeck and Thelen (2005), which point at the importance of hybrid or mixed scenarios, the following analysis investigates how different combinations of corporate and institutional changes in a region will influence the outcome of regional restructuring processes in response to increasing globalization. 
Table 12.1 refers to a specific regional context, such as an industrial district, that has developed a coherent industry structure characterized by localized learning dynamics and self-sustained innovation. As this regional context is challenged by a wave of globalization processes associated with widening markets, new international competition, and newly emerging technology centers, both industry and corporate structures in the region and the institutional context are put under pressure. Table 12.1 pictures six possible scenarios.

In a first set of scenarios, we assume that core parts of the corporate structure in the region do not respond adequately to globalization forces, continuing instead to collaborate with the same set of regional or national partners and relying on the same technologies as before. Although such an extreme scenario of industrial persistence may be hard to find in pure form, the Barletta footwear district in southern Italy illustrates a similar situation in which industrial structures have remained largely unchanged and challenges have not led to substantive innovation (Boschma \& Ter Wal, 2007). In such a case, a positive regional outcome cannot be expected, no matter what changes are implemented or occur in the institutional context. Indeed, the case of Barletta shows how a regional government has struggled to identify appropriate policies to support regional change in the face of a largely unresponsive industry structure (Rosati, 2016). If the institutional context in this situation largely persists, a loss of corporate competitiveness can result, with remaining regional learning processes unable to fundamentally solve globalization-related problems as actors lack access to wider knowledge ecologies. Such a situation could be related to institutional hysteresis (Setterfield, 1993) or regional lock-in (Martin $\&$ Sunley, 2006) and result in regional decline. If such a situation is coupled with efforts to radically change the institutional context, for instance, by generating new research organizations and establishing a fundamentally different set of support policies, the outcome may not be much different because the new institutional conditions are not likely to match the preexisting corporate structures persisting in this scenario. In the end, this can threaten the regional learning basis and result in a regional economic crisis. ${ }^{1}$ Hybrid institutional change would have a similar effect since the industry structure is persistent and does not adjust to globalization pressures.

The outcome is fundamentally different if core parts of the regional economy recognize the opportunities and threats associated with globalization and engage in corporate restructuring processes, for instance, by investing in new technologies and linking with international markets and technology centers through foreigndirect investments (e.g., Cantwell, 2014). Two cases that illustrate this situation are the Fermano and Riviera del Brenta footwear districts in the Third Italy (Buciuni \& Pisano, 2016; Cutrini, 2011; Rabellotti, 2004). In contrast to Barletta, these two districts underwent successful industrial reorganization and innovation processes,

\footnotetext{
${ }^{1}$ An example of such an outcome is the unsuccessful implementation of a science park and a related start-up strategy. It has long been known (e.g., Massey, Quintas, \& Wield, 1992) that such initiatives often only stimulate a limited response and little regional change, especially if public policies do not systematically link preexisting industries with the new developments.
} 
which were supported by regional policies and led to a changing institutional context. In our model, the precise outcome in a situation of substantial industrial and corporate change depends on the nature of the institutional adjustments that occur or are implemented, as indicated in Table 12.1. We distinguish three ideal-type situations:

(i) If the institutional context in terms of practices, regulations, and policies remains largely the same, new learning patterns may apply to those firms that engage in restructuring but exclude other regional actors. ${ }^{2}$ This may result in a progressive weakening of the regional learning platform and in a hollowingout process (Bathelt, 2009, 2013), resulting in slow regional change, limited economic growth, or even stagnation.

(ii) If radical changes are implemented within the institutional context by, for example, providing incentives for fundamental organizational shifts and introducing policies targeting new industries and start-up processes in new technology fields, the effects may be more promising, although the overall outcome may still be slow regional change and a bifurcation of the regional economic structure as traditional industries with persistent product and technology structures may be left behind.

(iii) The scenario is quite different, however, if one considers a hybrid structure of institutional adjustments involving, for instance, new policies directed, on the one hand, at modernization and adjustment processes in traditional industries and, on the other hand, at discontinuous technological change and the establishment of new industries. The example of the city of Prato pictures a similar situation, in which new Chinese entrepreneurs with novel manufacturing practices have entered the field of ready-to-wear fashion (pronta moda) and coexist with older Italian producers and their established manufacturing culture (Lan, 2015). It is through such hybrid settings that both established and new industry structures can be supported simultaneously and become integrated in overlapping learning cycles. This new structure then has the potential to transform existing learning patterns by integrating external actors and technological developments while encouraging localized feedback loops. It is such hybrid institutional change that may have the potential to preserve localized learning dynamics in the context of the global economy by combining fundamentally new institutional elements, which open up regional dynamics, with preexisting ones that encourage coherent regional linkages.

The importance of hybrid institutional change has also been pointed out in other literature on regional and national economic restructuring processes (e.g., Evenhuis, 2015; Streek \& Thelen, 2005). In their political economy analysis, Mahoney and Thelen (2010), for instance, identify multiple institutional strategies that link

\footnotetext{
${ }^{2}$ Although such an extreme situation may not be typical, it can occur when, for instance, regional policies and industrial practices focus on the traditional industry structure and do not support the development of or shift to new technologies. The case of Barletta (Rosati, 2016), but also the chemical industry regions in East Germany (Bathelt, 2013) may illustrate such a scenario.
} 
preexisting with new economic structures. These hybrid institutional adjustments range from displacement strategies (in which new institutions challenge and replace older ones) to conversion (in which established institutions are redesigned to new purposes), but also include strategies of layering (linking new elements to existing ones) and drift (where active adjustments are made to existing institutional settings). Pike et al. (2015) emphasize that such processes are not one-time adjustments but involve repeated restructuring and institutional calibration over an extended period. Which strategy is appropriate in a specific situation depends on the conditions of the challenges and the nature of the preexisting institutional context.

In sum, the argument behind the six regional restructuring scenarios in Table 12.1 suggests that the chances for successful regional economic change are best if, on the one hand, open and flexible adjustments in corporate structures occur and if, on the other hand, these are coupled with hybrid changes in the institutional context that address both the need for fundamental restructuring and the importance of securing regional coherence related to pre-existing competencies. Of course, the reality is more complex than expressed in this model because institutional contexts involve multiple levels consisting of organizations, rules, and stabilized practices. There is no guarantee that changes of these three levels will always be directed toward the same outcome. For the sake of our overall argument, we do not investigate the potential contingencies between these levels but focus on the entirety of the institutional context and on those changes with the most notable impact. ${ }^{3}$ Much research is still necessary to investigate the relationships that exist between the different levels of the institutional context.

\section{Methodology}

In this research we used the Canavese district in the Piedmont region of Italy as a theory-confirming typical case (Seawright \& Gerring, 2008; Tokatli, 2015) to investigate the restructuring processes in a region subjected to globalization processes that have challenged the sustainability of its localized learning system. Canavese, located north of Turin, can be viewed as a typical case because the region with its two organizational fields was able to successfully adjust to globalization pressures in a process enabled by hybrid institutional change, as we illustrate in the empirical part of our chapter. In the 1990s and 2000s, the region's dominant industries that developed historically around its two lead firms, Fiat and Olivetti, were challenged by new international competition from both highly developed industrial regions and low-labor-cost locations. At the same time, markets opened up and massive foreigndirect investment processes were undertaken by regional firms that developed a multinational structure with access to international markets and technologies. The

\footnotetext{
${ }^{3}$ Such contingencies are important, as illustrated by Glückler and Lenz (2016), who identify four different types of connections between the levels of interaction practices and rules and regulation in the institutional context: reinforcement, substitution, circumvention, and competition.
} 
Table 12.2 Economic demography of Canavese by industry groups; 1991, 2001, and 2011

\begin{tabular}{|c|c|c|c|}
\hline \multirow[b]{2}{*}{ Economic indicator } & 1991 & 2001 & 2011 \\
\hline & \multicolumn{3}{|c|}{ Industry total } \\
\hline Firms & 20,150 & 24,350 & 23,450 \\
\hline \multirow[t]{2}{*}{ Employees } & 95,800 & 102,100 & 87,000 \\
\hline & \multicolumn{3}{|c|}{ Industries related to Olivetti and Fiat ${ }^{1}$} \\
\hline Firms & 2,050 & 2,500 & 3,250 \\
\hline Employees & 31,400 & 28,350 & 31,000 \\
\hline Firms ( $\%$ of industry total) & 10.1 & 10.3 & 13.8 \\
\hline Employees ( $\%$ of industry total) & 32.8 & 27.8 & 35.6 \\
\hline $\begin{array}{l}\text { Employees in firms related to Olivetti \& Fiat with } \\
250 \text { or more employees }(\%)\end{array}$ & 38.4 & 20.1 & 17.4 \\
\hline $\begin{array}{l}\text { Employees in firms related to Olivetti \& Fiat with } \\
\text { less than } 250 \text { employees }(\%)\end{array}$ & 61.7 & 79.9 & 82.6 \\
\hline
\end{tabular}

Note. ${ }^{1)}$ Electronics, mechanics, steel molding, and components

Source: Computed from ISTAT $(1991,2001,2011)$ for the local labor market areas of Cirie, Ivrea, and Rivarolo Canavese

Canavese district managed these challenges quite well compared to other Italian regions (e.g., Buciuni \& Finotto, 2016). Between 1991 and 2011, the number of firms in the district increased from 20,150 to 23,450, while employment experienced a modest decline from 95,800 to 87,000 jobs (Table 12.2). Remarkably, the historically dominant automotive-metallurgical and electronics-mechatronics industries were able to restructure quite successfully and avoid a deeper regional crisis. In fact, employment in these industries remained constant between 1991 and 2011, at about 31,000 employees, and the number of firms increased by more than $50 \%$, from 2,050 to 3,250 . As a result, the regional share of these industries in employment and firm population increased during the 1990s and 2000s. This was due to tremendous startup and growth processes of small and medium-sized firms (less than 250 employees) and declining employment in large firms (250 or more employees).

We used an institutional perspective in our empirical analysis to investigate the successful restructuring processes in Canavese, applying a mixed-methods approach. On the one hand, this involved the collection of data, prior academic work, and policy reports, as well as the analysis of media and published interviews with key entrepreneurs and experts. We also conducted 18 semistructured interviews in "close dialogue" (Clark, 1998; Yin, 2009) with regional firms, planning authorities, institutional actors, and observers during the summer of 2015 to systematically collect information about the industrial and institutional adjustments that took place. We began the interviews with questions about the early development of the district and the institutional context that formed in terms of decisive organizations, policies, and interaction practices, and followed by questions about the role of globalization processes and the resulting threats to the competitiveness of local industries. Finally, interviewees were asked to compare today's industrial structure and institutional context with the earlier ones and to identify the changes that occurred. 
Interviewees were selected initially by contacting significant firms, policy and planning authorities, and university researchers, and subsequently through a snowball method. In the end, the various sources of information were triangulated with each other (Miles \& Huberman, 1994) in an attempt to reinterpret the regional restructuring process from an institutional perspective consistently across these various sources. Our methodology did not permit the direct study of interaction patterns between firms and their dynamics. Instead we based our implications on an interpretation of interview data and prior descriptions in the literature. The results presented in the following sections allowed us to draw conclusions about the different levels of the institutional context and their changes.

\section{The Socioeconomic Context of Canavese}

Historically, the Canavese region developed a spatial division of labor shaped by the two lead firms, Fiat and Olivetti. The region's northeastern part, around the city of Ivrea, Olivetti's headquarters location, specialized in electronics, information and communication technologies, and fine mechanics; the southern part near Turin in automotive manufacturing; and the northwestern part in mechanics and steel molding (Confindustria Canavese, 2015; Demetrio \& Giaccaria, 2010). The organizational fields surrounding Fiat and Olivetti and their respective institutional context are investigated in separate subsections below.

\section{Fiat and the Automotive-Metallurgical Industry}

Fiat was originally established in 1899 . The firm developed a network of production facilities in Turin and adjacent areas. Not only did Fiat become a major automotive producer in Europe, but the growth of the industry also spawned a broad network of local suppliers and service providers in western and southern Canavese. These suppliers were largely oriented toward Fiat, which purchased 70 to $80 \%$ of their products, and thus quite dependent on the automobile producer (Aimone Gigio, Cullino, Fabrizi, Linarello, \& Orame, 2012). Although Fiat had begun establishing international linkages to some European markets as early as the 1920s, these were mainly sales-oriented and focused on market integration. Global knowledge acquisition practices and international partnerships were seemingly less important. However, intense rationalization and cost-cutting pressures in the European automobile industry during the 1980s and 1990s led to international mergers and acquisitions (Hudson \& Schamp, 1995), exerting strong competitive pressures on Fiat. The consequences were restructuring processes and successive downsizing exercises aimed at cutting costs (Whitford \& Enrietti, 2005). The impact of these pressures on the supplier sector in the Canavese district was severe. Between 1991 and 2007, employment in car manufacturing decreased by over two-thirds-although component 
production did recover from an initial decline (Aimone Gigio et al., 2012). Resulting job losses were largely outweighed by the growth of other segments of the sector (Table 12.2). Despite this downturn, the automotive industry kept a strong foothold in the region. By 2009, 355 of Fiat's tier-1 suppliers were still located in the province of Turin, indicating that there was still a substantial local production system (Aimone Gigio et al., 2012).

Overall, the automotive-metallurgical production system in the Canavese region was highly dependent on Fiat. The firm had established a hierarchical division of labor and more or less dictated the conditions of producer-user relationships and the direction of technological change. Underlying this institutional context was a Fordist political economy with centralized capital-labor relations and strong unions (Bagnasco, 1986; Whitford \& Enrietti, 2005). Overall, disadvantages of the largefirm dominance in this industry were visible in the institutional context, which remained focused on the role of Fiat, with no particularly strong initiatives to support restructuring or the development of new industries. ${ }^{4}$ This part of the regional economy was clearly locked into the value chain of Fiat. Although specifically attuned to the context of the global automobile industry with linkages to international markets, the institutional context was fundamentally characterized by linkages within the regional production system and localized learning processes that were the drivers of regional growth.

\section{Olivetti and the Electronics-Mechatronics Industry}

Similar to Fiat, Olivetti was established as a family business in 1908 and developed a strong reputation as a producer of typewriters - a relatively new technology at that time. Olivetti internationalized its activities early on, exporting products to other countries and setting up market-related branches in Barcelona (1929) and Buenos Aires (1932). In the 1940s, Adriano Olivetti took control of the firm at a time when it had begun producing mechanic calculators and would soon develop electric typewriters (1950s). From these activities, the firm moved into technologically related segments of the electronics industry. Olivetti produced Italy's first electronic mainframe computer in 1959 and the first desktop computer worldwide (Programma 101) in 1965 (Brilliant, 1993; Olivetti, 1978-2009; Radogna, 1960). It also focused on electronic calculators, which were very successful. Olivetti eventually developed into a major player in the fields of electronics and office equipment with a total of 73,300 employees in 1970 (47\% of whom were in Italy) and a strong international presence (Barbiellini Amidei, Goldstein, \& Spadoni, 2010; Castagnoli, 2014).

\footnotetext{
${ }^{4}$ Interestingly, Fiat became a shareholder of Olivetti in 1964. The firm viewed this engagement primarily as a portfolio investment, rather than a strategy to develop competencies in the electronics sector. Later, when Olivetti ran into problems, Fiat used its ownership share in the firm to push for a sale and disintegration of the electronics division with the idea of strengthening other business segments of Olivetti (Gallino, 2003).
} 
By that time, the eastern part of Canavese had developed into a distinct electronics-mechatronics district. One interviewee who had experienced this process described in 2015 how there had been and still was a specific atmosphere in this district. Olivetti had a strong presence in the region, especially in Ivrea, and many families had members that worked for Olivetti. The firm also introduced an extensive corporate welfare system and supported employees' education programs. All this led to the development of collaborative capital-labor relationships in the region, strong employee loyalty, and high levels of social trust (Arrigo, 2003).

In the 1970s and 1980s, the firm continued to internationalize its activities through takeovers and partnerships and established research and development centers in leading high-technology regions such as Cupertino and New Canaan in the United States and Cambridge in the United Kingdom (Castagnoli, 2014). Canavese itself never developed into a similarly vibrant hot spot because it lacked, as our interviewees indicated, the necessary variety of competitors and technology leaders. Although Olivetti recognized the importance of being located close to leading-edge technology clusters, the establishment of research and development subsidiaries in such regions was not a substitute for a strong, localized knowledge ecosystem around its innovation and production base in Ivrea. One observer explained in an interview that there had been attempts to sell activities to and closely collaborate with another technology leader that could have provided better access to leading technology clusters, but that these attempts ultimately failed.

By the 1990s, Olivetti had lost its leading edge and was unable to cope with the technology dynamics driven by leading regions such as Silicon Valley. Like the minicomputer industry in Boston's Route 128 region (Saxenian, 1994), it ran into problems, leading to a shift toward telecommunications equipment. Not only did the firm lose its leadership, it also came under huge financial pressure as a result of problematic management decisions and its extensive corporate welfare system (Gallino, 2003). The firm had always been focused on hardware rather than software development and observers argued that Olivetti eventually failed because it was unable to exploit its first-mover advantages over American competitors and shift from electronics to computers in the early 1970s (Gallino, 2003; Perotto, 1995; Soria, 1979). ${ }^{5}$ Eventually, after a merger-takeover deal with the Telecom Italia group in 1999, the Olivetti brand name was marginalized and the firm's global leadership ultimately gone.

The regional impact of Olivetti's growth was just as significant as that of Fiat, albeit in a different way. Olivetti shaped a regional production system involving more interactive, trust-based collaboration than the one surrounding Fiat. Firms in this production system continued to be innovative in order to maintain their competitiveness. Olivetti supported university programs, professional schools, and even high schools to generate new talent and sustain existing capabilities (Arrigo, 2003). As pointed out in our interviews, the firm had developed a local supplier network somewhat like Fiat's but not nearly as large, with some $80 \%$ of it consisting of small

\footnotetext{
${ }^{5}$ It was no longer possible to exploit these advantages after Olivetti's electronics division was sold to General Electric in an attempt to overcome financial difficulties.
} 
family businesses (Michelsons, 1990). In contrast to Fiat, the supplier network was not structured hierarchically, instead being more open and based on interactive learning processes. Networks, as one expert told us, were often made up of former Olivetti employees who had gotten to know each other while working at that firm. These networks strengthened regional capabilities and led to the development of new technologies through firms such as Manital, CTS, ASIC, or Logitech-in other words, developments related to former innovations by Olivetti.

The corporate culture of Olivetti produced an interactive and open learning network based on trust. Early on, Adriano Olivetti developed strong linkages between the firm and the local community and pushed for active knowledge exchange and the idea of free knowledge access. In this spirit, the firm organized events with international designers to broaden its knowledge base beyond purely technical skills. Olivetti also established programs for its employees to regularly visit other production facilities and research centers. One of the interviewees suggested that because of these practices "Ivrea engaged with globalization [even] before globalization existed". These kinds of practices also made it possible for employees in the local production system to develop broad competences and contribute to the reproduction of innovation dynamics - albeit not quite at the level of diversity and competition as in leading technology clusters. When Olivetti finally faltered, extensive earlyretirement programs were negotiated with the national government. Although publicly funded, these programs were in line with Olivetti's practice of providing extensive corporate welfare to its employees (Arrigo, 2003; Censis, 2001; Provost \& Lai, 2016). The downside of these programs was a massive loss of local talent due to retirement. A consequence of this was that a local start-up boom, such as that seen in regions such as Boston or Silicon Valley, did not happen (Bathelt \& Glückler, 2012).

Although the context of the electronics-mechatronics district differed in important ways from the automotive industry in that it was less hierarchical, more open, and oriented (as early as the 1960s) toward international linkages, there were also fundamental similarities. Both organizational fields had a strong regional technology orientation, important localized learning processes, and were embedded in their respective localized manufacturing culture with limited linkages to global technology dynamics.

\section{From Localized Learning to Open Systems}

Having characterized the structure and evolution of the localized production and learning system in Canavese, we explain in this section how the region was able to overcome the threats and challenges accompanying economic globalization processes in the 1990s and 2000s. It is argued that this was possible because new economic activities were established and existing structures upgraded to meet the demands of open markets and international competition. This went hand in hand with fundamental changes across the entire institutional context as new players introduced new economic models, new policies were established, and practices 
evolved from localized learning to open systems integration. This process was also linked to and built upon existing institutional settings and former business legacies, enabling the inclusion of traditionally operating firms in the overall restructuring and modernization process. Interestingly, such hybrid institutional change occurred in both the automotive-metallurgical and electronics-mechatronics industries of the Canavese region. It enabled a push from localized learning and interaction toward open systems and global networks while actively embedding prior structures and competencies.

\section{Internationalization of Fiat}

Ongoing competitive pressures in the automobile industry during the 1990s led to further downsizing at Fiat but also supported opening up the industry's structure, which became more internationalized. Local supplier linkages substantially decreased, although some continuity remained, with about 30\% of Fiat's supplies still originating from the surrounding region (Aimone Gigio et al., 2012) in 2007. Suppliers reacted to the overall decline in orders from Fiat by actively strengthening other business segments and developing new customer relations beyond Turin and Canavese. In fact, significant internationalization processes gradually emerged in the supplier sector. This was also accompanied by efforts to move vigorously into new technology fields and to develop new products. Former Fiat managers also got involved in start-up processes, while building upon and strengthening preexisting network relations. One could say that the highly localized Fiat district was transformed into a more open and internationalized automobile district (Aimone Gigio et al., 2012; Whitford \& Enrietti, 2005). Automobile suppliers continued to collaborate locally with each other, albeit less so with Fiat. As one interviewee emphasized, "firms learned they have to collaborate to survive."

In contrast to Olivetti's strong social and cultural impact on the electronics industry and its labor force, the influence of Fiat was different and focused on the production system, being less concerned with the promotion of local socioeconomic development. Fiat's presence and its impact in the region continued to decline after the 1990s (Confindustria Canavese, 2015; Demetrio \& Giaccaria, 2010), with its headquarters eventually even moving to the Netherlands after Fiat took over Chrysler. Despite this, the firm maintained key research centers and university linkages in the region. Existing local research capabilities also attracted new firms from other regions and countries, including General Motors, which established its local Powertrain Europe research center in 2005 as a result of a partnership with Fiat and continued its activities in the area even after this agreement ended. Public policies supported the regional transformation of the automotive sector, although they were not decisive in triggering it. For instance, regional initiatives like the Aerospace Platform were established to strengthen the development of engine technologies in different applications. Other policies were put in place to manage areas with discontinued production, in particular through the regional agency Torino Nuova Economia, a public-private consortium that included Fiat (Torino Nuova Economia, n.d.). 
It appears that crucial elements of this institutional change resulted more from bottom-up processes than from top-down policies - as firms realized the significance of establishing new external markets, oriented themselves to their peers' strategies, and recognized the importance of regional networks. This went along with a decline of Fordist production structures, while preserving a distinct regional production context and building upon existing competencies. The process of hybrid institutional change was also supported by new firms and organizations and through government programs that introduced new policies.

\section{Institutional Legacy of Olivetti and Arduino}

In the electronics-mechatronics industry, Olivetti's legacy was just as important as that of Fiat in the automotive-metallurgical industry, although in different ways. Despite the fact that many employees went into early retirement and were no longer available in the local labor market when Olivetti downsized in the 1990s, start-up processes of new firms in related electronics fields were substantial (Ronca, 2015; Vanolo, 2008). Former Olivetti employees were heavily involved in such start-up processes, which benefited from these individuals' experience in the industry and their network linkages to other employees and firms in the region around Ivrea. One observer confirmed in an interview that new firms were often established by "sons of ex-Olivetti workers [on the basis of] inherited software skills." Through these processes, the regional industry opened up and became more diversified. The electronics sector expanded its basis (for instance in software development) and strengthened its established competencies in industrial design. Our interviewees often emphasized that Olivetti's prior activities had inspired the mindset of free knowledge and open exchange was now shared by so many people.

The firm Arduino, a pioneer in open-source technology, is a good example of the effects of Olivetti's institutional legacy of freely accessible and available knowledge. Arduino is a world-renowned producer of a programmable logic controller by the same name (Arduino, 2016; de Paoli \& Storni, 2011; Stückler, 2016) that permits its users to interact with their environment. The firm's economic success is based on the development of flexible, high-performance technologies available at a low price. Produced according to an open-source concept, the Arduino controller has become a worldwide standard for prototyping tasks applied in all sorts of electronics applications. Users of this technology form a diverse group made up of electronics firms and professionals, as well as hobbyists. The components can either be purchased as a package and assembled by the user or acquired as a preassembled product. In the latter case, the board carries the Arduino trademark. Interestingly, Arduino, a new player in the region, is directly linked to Olivetti's former activities and has benefited from that firm's previous regional research and labor market competencies. The Arduino technology was originally developed by the Interaction Design Institute that was linked to Olivetti and Telecom Italia's former CSELT laboratory. 
One former manager in the region described in an interview that "the Institute . . captured the entire innovative atmosphere [of the district]."

The firm Arduino is widely linked to its global user community that provides crucial input into product development but also promotes knowledge-sharing with the local district and thus supports local cohesion. While the trademark guaranteed local production in the Canavese region, the firm's open-source philosophy broke with the area's traditional localized division of labor (de Paoli \& Storni, 2011). Despite its success, the size of the firm and its direct regional impact via supplier relationships have remained limited. As one insider specified during our interviews, Arduino sold about one million boards and had an annual turnover of $€ 15$ million in 2014. Local supplier linkages during the time of our research were not extensive, consisting of about 10 firms directly involved in production with a total of about 80 employees. New hardware and software development largely took place in-house, while bug-fixing and learning relied on the global virtual user community. Still, local identification was apparently strong, with the firm achieving close to cult status in the region - as well as among community members worldwide. ${ }^{6}$

Altogether, these and related shifts generated the conditions for the former district to develop into a successful, more diverse information technology cluster. As argued above, the competencies of this cluster are associated with earlier technological successes but are also linked today to other information technology developments in the Turin region and have opened up spatial knowledge ecologies even further internationally than Olivetti's prior operations.

While Olivetti was still a leader in technology development, other information technology firms were attracted to the region (de Paoli \& Storni, 2011). They embedded their activities locally and established corresponding supplier linkages. This development contributed to the overall strength of the cluster and actively supported its renewal. These processes continued thereafter. New and existing research institutes in the region in fields such as engineering and industrial design produced new technologies and further improved the localized skill basis. Related innovations from firms such as Arduino became reference points in technology development and strengthened the local labor market. One interviewee emphasized that, as a consequence, "competencies are still in the territory [today]" and another observer added that "there is a specific cultural milieu in the field of coding [that has developed]". Overall, it seems that the local industry structure is still strong and develops international linkages, while district-like divisions of labor based on localized learning are somewhat weaker (see, also, Demetrio \& Giaccaria, 2010).

As in the case of the automotive-metallurgical industry, the electronics-mechatronics district benefited from hybrid institutional change supportive of a shift

\footnotetext{
${ }^{6}$ Despite this success, the future of Arduino is open at this point as the founders have been involved in an internal dispute since 2014 about the future development of the firm. As Arduino has increasingly come under cost pressure, some of the founders suggested shifting production to China while others insisted on preserving the local trademark. This dispute resulted in a lawsuit that was settled in October 2016. However, it remained unclear whether the production of boards will remain in Canavese (Simonetta, 2016).
} 
toward open learning and global knowledge circuits that built upon rather than giving up the distinct regional manufacturing culture and localized reference points. This shift affected the entire institutional context. Aside from new organizations, such as Arduino, that have pushed for institutional change and new economic practices, policies have been introduced to support and strengthen regional technological capabilities (Censis, 2001; Confindustria Canavese, 2015; Consorzio Aaster, 2013; Vanolo, 2008). For instance, the regional government founded research and development facilities in technologically related fields to establish an information technology innovation pole, and policies were introduced to strengthen the localized learning system by providing incentives for interfirm collaboration. In addition, university departments in engineering and communication technology were temporarily shifted from Turin to Ivrea, supporting the restructuring process. At the same time, diversification policies in the region attempted to link new initiatives to the institutional legacy of the region, by, for example, establishing a new biomedical technology park in buildings of the former Olivetti laboratories, thus linking the new development to the innovative spirit of Olivetti (Ronca, 2015). Despite such top-down shifts at the level of organizations, regulations and policies, important shifts in the institutional context occurred especially at the level of interaction and learning practices in a more bottom-up fashion.

\section{Conclusions and Policy Implications}

Using an institutional perspective to analyze regional economic change, we have suggested in this chapter that successful economic adaptation to external pressures can best be accomplished if industry and corporate restructuring processes are coupled with hybrid institutional change. Such hybrid adjustments combine new institutional settings to support new technological developments in certain fields with institutional continuity in others to actively integrate established industries and former corporate structures into the restructuring process. This theoretical claim has been justified through an ideal-type model of regional restructuring that is subject to adjustments in the institutional context and in industry and corporate structures as depicted in Table 12.1. The northern Italian district of Canavese, which is characterized by two organizational fields around its automotive-metallurgical and electronics-mechatronics industries, is used as a typical case to provide empirical support for this argument. Since the 1990s, the region experienced periods of economic turmoil and strong globalization pressures that threatened the cohesion of its economic structure and learning dynamics (dei Ottati, 2009a; Whitford, 2001). Although these organizational fields were characterized by dominant players, in other words, Fiat and Olivetti, the importance of both firms sank drastically over time as Fiat began to wind down its regional production system and Olivetti's activities faded away. Globalization pressures brought into question the value of the dominant localized learning models that had been so successful in previous periods. As a consequence of the decline of the lead firms, new innovative projects were initiated, regional networks cut, and new global knowledge linkages established. 
Interestingly, the shifts in the two organizational fields went along with similar hybrid adjustments in the institutional context that involved organizations, rules and regulations, and durable economic practices.

With its open-source philosophy, Arduino was a role model in generating virtual links with global user communities (Arduino, n.d.). The region's automotive-metallurgical and electronics-mechatronics industries established new international linkages with suppliers and technology partners and diversified their markets more than in previous periods. This process was supported by an institutional context linked to former legacies and reference points, helping to integrate long-established industrial activities broadly into the new economic structures and to maintain localized knowledge dynamics. At the same time, incentives were provided for discontinuous start-up and innovation dynamics, supported by new specialized research, training, and education facilities.

Canavese is, of course, a specific regional case and the argument about hybrid institutional change, although supported by other work on institutional change (e.g., Evenhuis, 2015; Mahoney \& Thelen, 2010), requires rigid empirical testing using a comparative approach. We therefore wish to exercise caution in drawing broad generalizations from this research. One could argue, for instance, that the specific structure of Canavese and the dominance of two large players make it difficult to transfer findings to other regional settings. While such implications would always be problematic, what makes the case of Canavese so useful and interesting is that it is much less homogenous than other industrial districts. It consists of two rather different organizational fields around the automotive-metallurgical and electronics-mechatronics industries, both of which had created a context of localized production and learning, as well as a specific local manufacturing culture. Remarkably, the challenges of globalization processes led to similar hybrid institutional adjustments. New firms and research organizations entered the regional economy and established new orientations and linkages. Existing firms opened up and engaged in new learning processes without giving up their former reference points and networks, with the automobile supplier industry, in particular, even strengthening regional collaboration. Regional change was driven by important bottom-up adjustments in the institutional context advanced by new firms and organizations, as well as by new support policies in a more top-down fashion.

In the end, however, in referring to a relational perspective of economic action and interaction (Bathelt \& Glückler, 2012), it is necessary to emphasize that the outcomes of such institutional change are contingent in nature and that success eventually depends on whether economic actors can be activated to engage in new opportunities and make respective business decisions. In the case of the Canavese district, there is no guarantee for successful growth in the future, because new developments as in the case of Arduino may be threatened through corporate power struggles or other influences. However, the opening up of the learning system, successful industry restructuring, and strong new linkages supported by hybrid institutional change have put the region into a favorable position from which it can react to and even proactively prepare for future changes in the global economic and technological landscape. 
Acknowledgements Some of the arguments developed in this chapter were initially presented in 2015 at the Global Conference on Economic Geography in Oxford and the Symposium on Knowledge and Institutions in Heidelberg. We are indebted to the participants of both events for stimulating discussions and suggestions. In particular, we would like to thank Johannes Glückler and Regina Lenz for including us in the Heidelberg Symposium and for providing detailed comments on an earlier draft. We also wish to thank James Bell and Daniel Hutton Ferris for superb edits and comments in the preparation of this chapter. This chapter is a revised and updated version of a SPACES online discussion paper by Bathelt and Conserva (2016).

\section{References}

Aimone Gigio, L., Cullino, R., Fabrizi, C., Linarello, A., \& Orame, A. (2012, February). Indotto Fiat o Motor City? La filiera dell'auto torinese di fronte alle nuove catene globali del valore [Fiat cluster or Motor City? Turin's automotive industry and the new global value chains]. Paper presented at the conference Le trasformazioni dei sistemi produttivi locali [The transformation of local production systems] organized by the Banca d'Italia and Department of Economics of the University of Bologna, Bologna. Retrieved from https://www.bancaditalia.it/pubblicazioni/ altri-atti-convegni/2012-trasform-sist-produttivi/Indotto_Fiat_o_Motor_City.pdf

Albino, V., Garavelli, A. C., \& Schiuma, G. (1998). Knowledge transfer and inter-firm relationships in industrial districts: The role of the leader firm. Technovation, 19, 53-63. doi:https:// doi.org/10.1016/S0166-4972(98)00078-9

Amin, A., \& Thrift, N. (1995). Living in the global. In A. Amin, \& N. Thrift (Eds.), Globalization, institutions, and regional development in Europe (2nd ed., pp. 1-22). Oxford, UK: Oxford University Press.

Arduino (n.d.). What is Arduino? Retrieved from https://www.arduino.cc/en/Guide/Introduction

Arrigo, E. (2003). Corporate responsibility in scarcity economy. The Olivetti case. Symphonya, 1(1), 114-134. doi:https://doi.org/10.4468/2003.1.10arrigo

Bagnasco, A. (1986). Torino: Un profilo sociologico [Turin. A sociological profile]. Turin: Einaudi.

Barbiellini Amidei, F., Goldstein, A., \& Spadoni, M. (2010). European acquisitions in the United States: Re-examining Olivetti-Underwood fifty years later. (Quaderni Di Storia Economica No. 2). Retrieved from https://www.bancaditalia.it/pubblicazioni/quaderni-storia/2010-0002/ Quaderno_storia_economica_1.pdf

Bathelt, H. (1998). Regionales Wachstum in vernetzten Strukturen: Konzeptioneller Überblick und kritische Bewertung des Phänomens 'Drittes Italien' [Regional growth in networked structures: Critical review and conceptualization of the phenomenon of the 'Third Italy']. Die Erde, 129, 247-271. Retrieved from http://www.digizeitschriften.de/dms/resolveppn/?PID=GDZ PPN003001822

Bathelt, H. (2009). Re-bundling and the development of hollow clusters in the East German chemical industry. European Urban and Regional Studies, 16, 363-381. doi:https://doi. org/10.1177/0969776409340193

Bathelt, H. (2013). Post-reunification restructuring and corporate re-bundling in the BitterfeldWolfen chemical industry, East Germany. International Journal of Urban and Regional Research, 37, 1456-1485. doi:https://doi.org/10.1111/j.1468-2427.2012.01194.x

Bathelt, H., \& Conserva, N. (2016). Globalization and institutional change in Italian industrial districts. SPACES online, 2016-02. Toronto and Heidelberg. www.spaces-online.com. Retrieved from http://www.spaces-online.uni-hd.de/include/SPACES_2016-02\%20Bathelt_Conserva. pdf

Bathelt, H., \& Glückler, J. (2012). Wirtschaftsgeographie: Ökonomische Beziehungen in räumlicher Perspektive [Economic geography: Economic relations in spatial perspective] (3rd ed.). Stuttgart: UTB-Ulmer. 
Bathelt, H., \& Glückler, J. (2014). Institutional change in economic geography. Progress in Human Geography, 38, 340-363. doi:https://doi.org/10.1177/0309132513507823

Becattini, G. (1990). The Marshallian industrial district as a socio-economic notion. In F. Pyke, G. Becattini, \& W. Sengenberger (Eds.), Industrial districts and inter-firm co-operation in Italy (pp. 37-51). Geneva: International Institute for Labour Studies.

Becattini, G., Bellandi, M., \& de Propris, L. (2009). Critical nodes and contemporary reflections on industrial districts: An introduction. In G. Becattini, M. Bellandi, \& L. de Propris (Eds.), A handbook on industrial districts (pp. xv-xxxv). Cheltenham: Edward Elgar.

Belussi, F., \& Pilotti, L. (2002). Knowledge creation, learning and innovation in Italian industrial districts. Geografiska Annaler, 84 B, 125-139. doi:https://doi. org/10.1111/j.0435-3684.2002.00118.x

Belussi, F., \& Sedita, S. R. (2012). Industrial districts as open learning systems: Combining emergent and deliberate knowledgef structures. Regional Studies, 47, 165-184. doi:https://doi.org/ 10.1080/00343404.2010.497133

Boschma, R., \& Frenken, K. (2009). Some notes on institutions in evolutionary economic geography. Economic Geography, 85, 151-158. doi:https://doi.org/10.1111/j.1944-8287.2009.01018.x

Boschma, R., \& Ter Wal, A. L. J. (2007). Knowledge networks and innovative performance in an industrial district: The case of a footwear district in the south of Italy. Industry and Innovation, 14, 177-199. doi:https://doi.org/10.1080/13662710701253441

Brilliant, E. (1993). Theory and reality in the vision of Adriano Olivetti. Voluntas, 4, 95-114. doi:https://doi.org/10.1007/BF01398386

Brusco, S. (1982). The Emilian model: Productive decentralisation and social integration. Cambridge Journal of Economics, 6, 167-184. doi:https://doi.org/10.1093/oxfordjournals.cje. a035506

Buciuni, G., \& Finotto, V. (2016). Innovation in global value chains: Co-location of production and development in Italian low-tech industries. Regional Studies, 50, 2010-2023. doi:https://doi. org/10.1080/00343404.2015.1115010

Buciuni, G., \& Pisano, G. (2016, October). Knowledge integrators and the survival of manufacturing clusters. Paper presented at the iBEGIN conference on International Business, Economic Geography, and Innovation, Philadelphia.

Camuffo, A., \& Grandinetti, R. (2011). Italian industrial districts as cognitive systems: Are they still reproducible? Entrepreneurship \& Regional Development, 23, 815-852. doi:https://doi. org/10.1080/08985626.2011.577815

Cantwell, J. (Ed.). (2014). Location of international business activities: Integrating ideas from research in international business, strategic management and economic geography. Basingstoke: Palgrave Macmillan.

Castagnoli, A. (2014). Across borders and beyond boundaries: How the Olivetti company became a multinational. Business History, 56, 1281-1311. doi:https://doi.org/10.1080/00076791.201 3.876534

Censis (2001). Reinventare il Canavese: Strategie per il riposizionamento del sistema economico e sociale [Reinventing Canavese: Strategies to readjust the economic and social system]. Milan: Franco Angeli.

Clark, G. L. (1998). Stylized facts and close dialogue: Methodology in economic geography. Annals of the Association of American Geographers, 88, 73-87. doi:https://doi. org/10.1111/1467-8306.00085

Clark, G. L., \& Monk, A. H. B. (2013). The scope of financial institutiosns: In-sourcing, outsourcing and off-shoring. Journal of Economic Geography, 13, 279-298. doi:https://doi. org/10.1093/jeg/lbs061

Confindustria Canavese (2015). Strategie per il Canavese: Dieci anni di studi e ricerche sul territorio [Strategies for Canavese: Ten years of studies and research about the territory]. Ivrea: Ivrea Grafica.

Consorzio Aaster (2013). Strategie per il Canavese. Cosa sarà. Ipotesi di futuro e scenari di sviluppo [Strategies for Canavese. What will happen. Hypotheses for the future and scenarios for development]. Canavese. Retrieved from http://docplayer.it/12780715-Strategie-per-il-canavese-cosa-sara-ipotesi-di-futuro-escenari-di-sviluppo.html 
Cutrini, E. (2011). Moving eastwards while remaining embedded: The case of the Marche footwear district, Italy. European Planning Studies, 19, 991-1019. doi:https://doi. org/10.1080/0954313.2011.571062

dei Ottati, G. (2009a). An industrial district facing the challenges of globalization: Prato today. European Planning Studies, 17, 1817-1835. doi:https://doi.org/10.1080/09654310903322322

dei Ottati, G. (2009b). Semi-automatic and deliberate actions in the evolution of industrial districts. In G. Becattini, M. Bellandi, \& L. de Propris (Eds.), A handbook on industrial districts (pp. 204-215). Cheltenham: Edward Elgar.

Demetrio, V., \& Giaccaria, P. (2010). Geografia del sistema manifatturiero piemontese: Nuove forme di organizzazione e coordinamento [Geography of the Piedmontese manufacturing system: New forms of organization and coordination]. Rome: Carocci.

de Paoli, S., \& Storni, C. (2011). Produsage in hybrid networks: Sociotechnical skills in the case of Arduino. New Review of Hypermedia and Multimedia, 17, 31-52. doi:https://doi.org/10.10 80/13614568.2011.552641

DiMaggio, P. J., \& Powell, W. W. (1983). The iron cage revisited: Institutional isomorphism and collective rationality in organizational fields. American Sociological Review, 48, 147-160. Retrieved from http://www.jstor.org/stable/2095101

Douglas, Y., \& Hargadon, A. (2017). Domesticating innovation-Designing revolutions. In H. Bathelt, P. Cohendet, S. Henn, \& L. Simon (Eds.), The Edward Elgar companion to innovation and knowledge creation (pp. 152-164). Cheltenham: Edward Elgar.

Evenhuis, E. (2015, August). Path dependency across scales: Towards a more differentiated and multi-scalar perspective on regional institutional change. Paper presented at the Global Conference on Economic Geography, Oxford.

Gallino, L. (2003). La scomparsa dell'Italia industriale [The demise of the industrial Italy]. Turin: Einaudi.

Gertler, M. S. (2010). Rules of the game: The place of institutions in regional economic change. Regional Studies, 44, 1-15. doi:http://10.1080/00343400903389979

Giblin, M. (2011). Managing the global-local dimensions of clusters and the role of 'lead' organizations: The contrasting cases of the software and medical technology clusters in the west of Ireland. European Planning Studies, 19, 23-42. doi:https://doi.org/10.1080/09654313.201 1.530529

Glückler, J., \& Bathelt, H. (2017). Institutional context and innovation. In H. Bathelt, P. Cohendet, S. Henn, \& L. Simon (Eds.), The Edward Elgar companion to innovation and knowledge creation (pp. 121-137). Cheltenham: Edward Elgar.

Glückler, J., \& Lenz, R. (2016). How institutions moderate the effectiveness of regional policy: A framework and research agenda. Investigaciones Regionales-Journal of Regional Research, 36, 255-277. Retrieved from http://hdl.handle.net/10017/28164

Hassink, R. (2010). Regional resilience: A promising concept to explain differences in regional economic adaptability? Cambridge Journal of Regions, Economy and Society, 3, 45-58. doi:https://doi.org/10.1093/cjres/rsp033

Hassink, R., \& Shin, D.-H. (2005). Guest editorial: The restructuring of old industrial areas in Europe and Asia. Environment and Planning A, 37, 571-580. doi:https://doi.org/10.1068/ a36273

Hodgson, G. M. (1988). Economics and institutions: A manifesto for a modern institutional economics. Cambridge, UK: Polity.

Hudson, R., \& Schamp, E. W. (Eds.) (1995). Towards a new map of automobile manufacturing in Europe? New production concepts and spatial restructuring. Berlin: Springer.

ISTAT (2001). $8^{\circ}$ Censimento Generale Dell'industria E Dei Servizi [8th general census of industry and services]. Retrieved from http://dwcis.istat.it/cis/index.htm

ISTAT (2001). $8^{\circ}$ Censimento Generale Dell'industria E Dei Servizi [8th general census of industry and services]. Retrieved from http://dwcis.istat.it/cis/index.htm

ISTAT (2011). $9^{\circ}$ Censimento Generale Dell'industria E Dei Servizi [9th general census of industry and services]. Retrieved from http://dati-censimentoindustriaeservizi.istat.it/Index.aspx

Lan, T. (2015). Industrial district and the multiplication of labour: The Chinese apparel industry in Prato, Italy. Antipode, 47, 158-178. https://doi.org/10.1111/anti.12104 
Mahoney, J., \& Thelen, K. (2010). A theory of gradual institutional change. In J. Mahoney, \& K. Thelen (Eds.), Explaining institutional change: Ambiguity, agency, and power (pp. 1-37). Cambridge, UK: Cambridge University Press.

Martin, R., \& Sunley, P. (2006). Path dependence and regional economic evolution. Journal of Economic Geography, 6, 395-437. doi:https://doi.org/10.1093/jeg/lbl012

Martin, R., \& Sunley, P. (2015). On the notion of regional economic resilience: Conceptualization and explanation. Journal of Economic Geography, 15, 1-42. doi:https://doi.org/10.1093/jeg/ lbu015

Massey, D., Quintas, P., \& Wield, D. (1992). High-tech fantasies: Science parks in society, science and space. London: Routledge.

Michelsons, A. (1990). Mercati, tecnologie e imprenditori nel Canavese [Markets, technologies, and entrepreneurs in Canavese]. In R. Maglione, A. Michelsons, \& S. E. Rossi (Eds.), Economie locali tra grande e piccola impresa: Il caso di Ivrea e del Canavese [Local economies between large and small firms: The case of Ivrea and Canavese] (pp. 109-166). Turin: Fondazione Adriano Olivetti.

Miles, M. B., \& Huberman, A. M. (1994). Qualitative data analysis: An expanded sourcebook (2nd ed.). Thousand Oaks: Sage.

North, D. C. (1990). Institutions, institutional change and economic performance. Cambridge, UK: Cambridge University Press.

North, D. C. (1991). Institutions. Journal of Economic Perspectives, 5, 97-112. doi:https://doi. org/10.1257/jep.5.1.97

Olivetti (1978-2009). Olivetti: Storia di un'impresa [Olivetti: History of an enterprise]. Associazione Archivio Storico Olivetti. Retrieved from http://www.storiaolivetti.it

Perotto, P. G. (1995). Programma 101. L'invenzione del personal computer: Una storia appassionante mai raccontata [Programma 101. The invention of personal computers: A fascinating story never described]. Milan: Sperling \& Kupfer.

Pike, A., Marlow, D., McCarthy, A., O’Brien, P., \& Tomaney, J. (2015). Local institutions and local economic development: The Local Enterprise Partnerships in England, 2010-. Cambridge Journal of Regions, Economy and Society, 8, 185-204. doi:https://doi.org/10.1093/cjres/rsu030

Provost, C., \& Lai, S. (2016, April 13). Story of cities \#21: Olivetti tries to build the ideal 'human city' for its workers. The Guardian. Retrieved from https://www.theguardian.com/cities/2016/ apr/13/story-cities-21-adriano-olivetti-ivrea-italy-typewriter-factory-human-city

Rabellotti, R. (2004). How globalization affects Italian industrial districts: The case of Brenta. In H. Schmitz (Ed.), Local enterprises in the global economy: Issues of governance and upgrading (pp. 140-173). Cheltenham: Edward Elgar.

Radogna, P. (1960). Adriano Olivetti: Some notes on his contribution to planning. The Town Planning Review, 31, 182-186. Retrieved from https://www.jstor.org/stable/40178354

Rodríguez-Pose, A., \& Storper, M. (2006). Better rules or stronger communities? On the social foundations of institutional change and its economic effects. Economic Geography, 82, 1-25. doi:https://doi.org/10.1111/j.1944-8287.2006.tb00286.x

Ronca, C. (2015). Trasformazione di un sistema produttivo locale e linee guida per una 'mappa delle competenze': Il caso del Canavese [Transformation of a local production system and guidelines for a 'map of competences': The case of Canavese]. Working Paper on Knowledge Society No. 08. Ivrea: Fondazione Adriano Olivetti. Retrieved from http://www.fondazioneadrianolivetti.it/_images/pubblicazioni/collana/032615060354WP_Trasformazione\%20 di\%20un\%20sistema\%20produttivo\%20locale_vers.pdf

Rosati, D. (2016). Regional inequalities in the commodity of trust: The case of two industrial districts in the Italian footwear industry. SPACES online, 2016-01. Toronto and Heidelberg. www.spaces-online.com. Retrieved from http://www.spaces-online.uni-hd.de/include/ SPACES_2016-01\%20Rosati.pdf

Saxenian, A. L. (1994). Regional advantage: Culture and competition in Silicon Valley and Route 128. Cambridge, MA: Harvard University Press.

Scott, A. J. (1998). Regions and the world economy: The coming shape of global production, competition, and political order. Oxford, UK: Oxford University Press. 
Seawright, J., \& Gerring, J. (2008). Case selection techniques in case study research: A menu of qualitative and quantitative options. Political Research Quarterly, 61, 294-308. doi:https://doi. org/10.1177/1065912907313077

Setterfield, M. (1993). A model of institutional hysteresis. Journal of Economic Issues, 27, 755-774. Retrieved from https://www.jstor.org/stable/4226717

Simonetta, B. (2016, October 2). Arduino, scoppia la pace: Raggiunto l'accordo sulla proprietà del marchio [Arduino, its reconciliation. Agreement achieved on the property of the trademark]. Il Sole 24 Ore. Retrieved from http://www.ilsole24ore.com/art/tecnologie/2016-10-02/arduinoscoppia-pace-raggiunto-accordo-proprieta-marchio-113139.shtml?uuid=ADIz2tUB

Soria, L. (1979). Informatica: Un'occasione perduta. La divisione elettronica dell'Olivetti nei primi anni del centrosinistra [Computers: A lost chance. Olivetti's electronics division in the first years of center-left governments]. Turin: Einaudi.

Streeck, W., \& Thelen, K. (2005). Introduction: Institutional change in advanced political economies. In W. Streeck, \& K. Thelen (Eds.), Beyond continuity: Institutional change in advanced political economies (pp. 1-39). Oxford, UK: Oxford University Press.

Stückler, M. (2016, July 31). Computer für Bastler: Was ist eigentlich ein Arduino? [Computers for hobbyists: What actually is an Arduino?]. Spiegel Online. Retrieved from http://www.spiegel. de/netzwelt/gadgets/arduino-erklaert-das-kann-der-microcontroller-a-1105328.html

Tokatli, N. (2015). Single-firm case studies in economic geography: Some methodological reflections on the case of Zara. Journal of Economic Geography, 15, 631-647. doi:10.1093/jeg/ lbu013

Torino Nuova Economia (n.d.). Retrieved from http://www.torinonuovaeconomia.it/organigramma_eng.php

Vanolo, A. (2008). The electronic and mechatronics industry in Ivrea. In IGEAT-ULB, Politecnico di Milano, \& UMS Riate (Eds.), The impact of globalisation and increased trade liberalisation on European regions (pp. 37-52). Study for the General Direction REGIO of the European Commission. Retrieved from http://ec.europa.eu/regional_policy/sources/docgener/studies/ pdf/impact_liberalisation_a2.pdf

Whitford, J. (2001). The decline of a model? Challenge and response in the Italian industrial districts. Economy and Society, 30, 38-65. doi:https://doi.org/10.1080/03085140020019089

Whitford, J., \& Enrietti, A. (2005). Surviving the fall of a king: The regional institutional implications of crisis at Fiat auto. International Journal of Urban and Regional Research, 29, 771-795. doi:https://doi.org/10.1111/j.1468-2427.2005.00621.x

Whitford, J., \& Potter, C. (2007). Regional economies, open networks and the spatial fragmentation of production. Socio-Economic Review, 5, 497-526. doi:https://doi.org/10.1093/ser/ mwm004

Yin, R. K. (2009). Case study research: Design and methods (4th ed.). Thousand Oaks: Sage.

Open Access This chapter is licensed under the terms of the Creative Commons Attribution 4.0 International License (http://creativecommons.org/licenses/by/4.0/), which permits use, sharing, adaptation, distribution and reproduction in any medium or format, as long as you give appropriate credit to the original author(s) and the source, provide a link to the Creative Commons license and indicate if changes were made.

The images or other third party material in this chapter are included in the chapter's Creative Commons license, unless indicated otherwise in a credit line to the material. If material is not included in the chapter's Creative Commons license and your intended use is not permitted by statutory regulation or exceeds the permitted use, you will need to obtain permission directly from the copyright holder. 